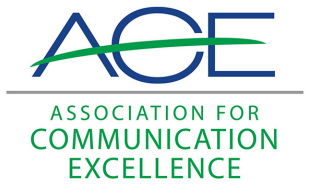

Journal of Applied Communications

\title{
"Do Newspapers Add to Citizen Feelings of Community Closeness?"; Time for a New Look at Training for Rural-Based Development Projects
}

Debrah Jefferson

Jim King

Follow this and additional works at: https://newprairiepress.org/jac (c) (i) (9)

This work is licensed under a Creative Commons Attribution-Noncommercial-Share Alike 4.0 License.

\section{Recommended Citation}

Jefferson, Debrah and King, Jim (1986) "'Do Newspapers Add to Citizen Feelings of Community Closeness?"; Time for a New Look at Training for Rural-Based Development Projects," Journal of Applied Communications: Vol. 69: Iss. 2. https://doi.org/10.4148/1051-0834.1612

This Review is brought to you for free and open access by New Prairie Press. It has been accepted for inclusion in Journal of Applied Communications by an authorized administrator of New Prairie Press. For more information, please contact cads@k-state.edu. 
"Do Newspapers Add to Citizen Feelings of Community Closeness?"; Time for a New Look at Training for Rural-Based Development Projects

\begin{abstract}
Reviews of "Do Newspapers Add to Citizen Feelings of Community Closeness?" by C.N. Olien, G.A.

Donohue, and P.J. Tichenor; Time for a New Look at Training for Rural-Based Development Projects, by John L. Woods.
\end{abstract}




\section{Reviews}

"Do Newspapers Add to Citizen Feelings of Community Closeness?"' C.N. Olien, G.A. Donohue, and P.J. Tichenor, in Sociology of Rural-Life, St. Paul: University of Minnesota, Vol. 7, No. 4, Summer 1985, pp. 3-4.

Extension information specialists continually seek answers to questions about the importance of small-town newspapers in the rural community. Several assumptions are made about the differences of community size and the role of papers. Foremost, is the paper serving as the eyes and ears in the small community and fostering the sense of closeness? It is assumed that urban/suburban dwellers might value lifestyles but feel less close to the community than those in small, rural towns.

Extension specialists are told to use the mass media, especially the small-town paper because of its importance. They are told to look at the audience and write to that audience's needs. These directions are given because newspapers are perceived as a link to community identification, involvement, and satisfaction. The Minnesota study conducted by Olien, Donohue, and Tichenor indicates this may not be true.

The Minnesota researcher's hypotheses states:

Because the interlocking relationship of the small, rural community is reflected in the local newspaper, one might expect that paper to contribute directly and strongly to further feelings of closeness, more so than might occur in the urban and suburban setting.

They also proposed an alternative hypothesis:

Because of community structure, it is expected that mass media become more essential in the more pluralistic structure typified by large metro areas. 
To examine the validity of the hypothesis, 10 Minnesota communities were surveyed in March, April, and May, 1978. There was a mix of urban, suburban, and rural areas. The research article highlighted results from two measures of community closeness extracted from 1,100 telephone interviews. One was a five-item scale measuring attitudes regarding the degree of closeness a respondent felt to community organizations, clubs, churches, friends, and neighbors. Responses ranged from "very close" to "not very close." The other measure was a single item for overall closeness. Newspaper reading, knowledge of local issues, age, and formal education also went into the interview analysis.

The general results indicate small, homogeneous rural communities express more closeness than the pluralistic urban communities. However, newspaper use is more strongly correlated with closeness in the pluralistic suburbs than in the rural communities. In essence, the data do not support the assumption that small-town papers contribute more to building community closeness than urban/suburban papers.

The research indicates that differences in community composition may be the reason for differences in newspaper role. The small town depends on face-to-face communication while the urban areas rely on mass media to provide information exchange. The researchers stressed the findings do not mean papers play lesser roles in rural communities, but "the consequences of media dissemination and use must be seen in the context of the community structure." The data suggest that the newspaper should be viewed as a catalyst rather than as a single determinant of community response.

When analyzing data on newspaper reading, the researchers found a positive correlation between local knowledge and closeness in all communities. But its magnitude is greatest in a small rural town served by a weekly paper. There, knowledge is primarily the result of reading alone, rather than reading augmented by other forms of communication.

Their conclusion indicates: (1) a feeling of community closeness is stronger in homogeneous rural communities than elsewhere; (2) newspaper reading within the rural community is not as strong as within the urban community; (3) reading contributes more closeness in the metro area; and (4) both reading and closeness contribute to knowledge of public affairs in the suburban areas. But only reading contributes to 
knowledge, not closeness, in the rural areas. Therefore, the nature and role of the newspaper varies with communities.

The results of this study support the message to extension field staff-learn your community and analyze it based on individual conditions. What works in one type of community may not apply to another.

An interesting follow-up research study should measure electronic media's role in community closeness-building and knowledge. Media mixes are growing in importance in extension work; therefore, it would be beneficial to find out the importance of other media, in building closeness, as it is with newspapers.

Debrah Jefferson

University of Missouri-Columbia

Time for a New Look at Training for Rural-Based Development Projects. John L. Woods. UNDP Asia and Pacific Programme for Development Training and Communication Planning, Bangkok, 1984.

People working in development often think of training as the solution to a host of ailments. Too often they approach and implement training from the top down.

In many instances, this traditional view of training has worked in the short term. But it has left a legacy of unsatisfactory results. Written for DTCP, John Woods' paper pulls together the best of the old training perspectives and merges it with a systems approach based on Woods' ten years of on-the-job, in-the-field experience.

Woods argues that training is often looked at as an end in itself; the question "training for what?" is often avoided. $\mathrm{He}$ recommends that governments and international agencies study an overall approach to developing human resources and improving job performance, rather than focusing specifically on the training component.

If implemented within a development program, this approach to training is job related, participant centered, and cost effective. The author presents a 14-step, human resources development model to implement this "ideal approach." 
First, Woods suggests reviewing the overall project to list and understand its basic objectives. The review will point to organizational manpower needs. Once these are determined, they are followed by manpower planning which culminates in "performance oriented" job descriptions.

These three steps serve as a basis for the rest of the activities: determining and packaging the subject matter; job applicant study before recruitment; proficiency exams and internships; shortened preservice training; initial field work; planning in-service training for interns; performance review and testing; career development plans; long-term, in-service plans; periodic job performance reviews; and mechanisms to monitor, evaluate, and improve the human resource development process. Woods expands on each of these complex activities with sufficient comments and suggestions, noting that they will have to be adapted to each specific situation. This system approach is not a linear, sequential series of tasks, rather it is a long-term, interlinked ribbon designed to foster human resource development.

How do you go about introducing this complex approach to ongoing projects? It requires many decisions by many people while the projects develop. Since Woods' systematic approach demands professional training expertise and an infrastructure, it should be introduced and tested gradually, building into an overall approach. The author offers seven suggestions to assist in developing this type of training: verifying content, improving quality, evaluating and monitoring, inservice planning, long-range manpower planning and recruitment, analyzing constraints, and reviewing the overall approach. These suggestions are linked to the training model and provide the implementation and action steps.

This short, well written paper shows the practitioner the complex interactions necessary for effective training. Governments and agencies are urged to focus on the entire process of developing human resources. Training is but one tool to achieve that objective.

"Time for a New Look. . "' is available as document RB\#353 from: Publications Editor, UNDP/DTCP, P.O. Box 2-147, Bangkok 10200, Thailand. 